\title{
1. Waging accountability: why investigative journalism is both necessary and insufficient to transforming immigration detention
}

Nina Bernstein

\section{INTRODUCTION}

Several years after I began writing about immigration for the New York Times, a lawyer sent me an email describing calls he had received from two clients who were being held at an immigration detention center in Elizabeth, New Jersey. The callers said that a badly injured mannamed "something like Aboubakar" - had been left in an isolation cell, and then taken away near death. "I have no first-hand knowledge," the lawyer wrote me. "I just thought you might be interested in looking in to it."

This is the way an investigative reporting project often begins, with a tip, a bit of fragmentary information that stirs larger concerns and questions already accumulating on a reporter's beat. Thanks to a few public interest lawyers toiling in the bowels of immigration detention, I already knew quite a bit about this system. A secretive, billion-dollar hodgepodge of profit-making prisons, county jails and federal detention centers, it was the fastest-growing form of incarceration in the United States, with almost none of the due process safeguards that most New York Times readers took for granted. Certainly I was interested in looking into the case. But advocates who frequented the Elizabeth Detention Center said they were unaware of it, and at Immigration and Customs Enforcement (ICE) - the agency of the Department of Homeland Security that oversees immigration detention - a spokesperson insisted that without the detainee's full name and eight-digit alien registration number, he could not even check my information.

That was a lie. Years later, I would read the agency's "significant incident report" about my inquiry, and see in black and white that even 
as the spokesperson, Michael Gilhooly, was rebuffing my questions, he was sharing details about the case with ICE officials in Newark and Washington, and working with them to draft an exculpatory narrative that could stymie public scrutiny. When I was making those first phone calls, the man I was asking about was still alive, in a coma after emergency surgery for a skull fracture and multiple brain hemorrhages. He never awakened. When he died months later, on 30 May 2007, leaving family members on two continents trying to find out why, I still didn't even know his name. And I didn't know that the day after the man's death, the director of the Newark field office of ICE, Scott Weber, recommended the unusual step of paying to send his body to Guinea for burial, to prevent the widow from showing up in the United States for a funeral and drawing unwanted news coverage. Still, I knew enough to recognize that I had not been told the truth, and that investigative reporting, not conventional reporting, was the best hope of learning it.

There is no settled definition of investigative reporting, and many veteran journalists legitimately maintain that all good reporting is investigative. But a handbook on investigative journalism published by the United Nations Educational, Scientific and Cultural Organization (UNESCO), despite having some serious flaws, defines the difference well: "Investigative journalism involves exposing to the public matters that are concealed - either deliberately by someone in a position of power, or accidentally - behind a chaotic mass of facts and circumstances that obscure understanding. It requires using both secret and open sources and documents," gathered at the reporter's initiative. Conventional news reporting, in contrast, "depends largely and sometimes entirely on materials provided by others (such as police, governments, companies, etc.); it is fundamentally reactive, if not passive."

In the realm of immigration detention, the role of public affairs officers, I learned, was to help hide, manipulate and airbrush reality. Without investigative journalism sufficiently probing to pierce that obfuscation, even the need for change could go unrecognized.

Journalism has a privileged place in a democracy, especially in the United States, because, in theory, by informing citizens, journalism works to hold government to public account. But the reality unfolds at a far messier intersection between the politics of reform and the contingencies and conventions of even the most robust news operation. In the end, my experience probing for the facts and the larger meaning of deaths in detention illustrates why such reporting may be both necessary and insufficient to spur fundamental change. 


\section{INVESTIGATING DEATHS IN DETENTION}

In 2007, I was not the only person hunting for facts about deaths in detention. By the late spring of that year, Tom Jawetz, then a lawyer with the American Civil Liberties Union, had cobbled together a list of 19 or 20 people known to have died in detention since 2004 while facing deportation. One of those cases I myself had brought to light in a local feature story: Nery Romero, a 22-year-old Salvadoran with a badly injured leg had hanged himself in the Bergen County jail in February 2007 after days of crying out for painkillers that he never received. But as I dug deeper to try to report a national article about deaths in detention, an ICE spokeswoman I had been pressing for weeks gave me some startling information: the dead numbered not 20, but at least 62 .

Where, when and how did they die? What were their names? The ICE spokeswoman refused to say. The government's silence was all the more disturbing because of what I was able to learn about the dead whose names we knew. ${ }^{2}$ There was, for example, Sandra Kenley, a long-time legal permanent resident who was returning home from her native Barbados in 2005 when she was swept into detention based on two old misdemeanor drug convictions. Seven weeks later, she was dead in a rural Virginia jail where she had complained of not receiving her medication for high blood pressure. Her only court appearances had been by video monitor, waiting for a volunteer lawyer who never came.

There was Abdoulai Sall, 50, an auto mechanic from Guinea who had a lawyer and no criminal record but who nevertheless was seized during an immigration interview. He had a severe kidney ailment and despite his lawyer's efforts, he, too, complained of not getting his medicine as he sickened in a barracks-style unit of the Piedmont Regional Jail in Farmville, Virginia. Fellow detainees described Sall huddling next to the unit dryer for warmth, barely able to walk. "The medical staff told him they don't have what he needs because immigration don't pay enough money," one detainee wrote.

There was Young Sook Kim, a Korean woman held at a privately run detention center in Albuquerque. Fellow detainees told a lawyer that she had been in pain, pleading for medical care for weeks, but received scant attention until her eyes yellowed and she stopped eating. She died of pancreatic cancer in federal custody on 11 September 2006, one day after she was taken to a hospital.

In a front-page article in June 2007, I wrote, "No government body is charged with accounting for deaths in immigration detention. But as the system balloons to meet demands for stricter enforcement of immigration laws, deaths in custody - and the secrecy and confusion around 
them-are drawing increased scrutiny from lawmakers and from government investigators." And, I could have added, from a few journalists. I had, of course, filed a Freedom of Information Act request for the basic information that ICE refused to reveal: the names and ages of people who had died in its custody, the location and causes of their deaths.

The federal Freedom of Information Act (FOIA) is a much-celebrated, but increasingly imperfect, tool of investigative journalism in the United States. When the Act was passed by Congress in 1966, at the height of the Cold War, it was considered the first modern law of its kind in the world, a beacon lighting the way to a public "right to know." But as Michael Schudson, a leading historian of the news media, has written, the origin of the Act was an effort to keep the executive branch under check by Congress; it was driven less by a belief in the need for transparency in a democracy, as by "a fervent desire to show that the free and democratic political institutions and free market economy in the US lived up to its reputation as a contrast to the enemy's system - the closed society of the Soviet Union."3

In 1974, after the Watergate scandal, Congress added deadlines and sanctions to the law to enforce compliance. Though the law required the agency to answer a simple request like mine within 20 business days, no one at the New York Times was surprised when ICE initially responded with silence. I knew from experience that at best I was in for a wait of many months, and at worst a denial that could only be appealed in court. So I wrote my national piece without the information that the agency should have readily provided and went back to covering other stories on the busy New York Times "Metro" section immigration beat.

Months later, around Thanksgiving, an envelope showed up in my mailbox in the newsroom. Inside was a chart listing 66 names of people who had died in immigration detention, with their dates of birth and death, the locations where they had been held, where they had died and the cause of death. My FOIA request had been granted. I still remember the uncanny feeling of recognizing the name that had eluded me- "something like Aboubakar" was in fact Boubacar Bah. He was, I eventually discovered, a husband and father who came from Guinea to New York on a tourist visa in 1998 and overstayed. A tailor who shared an apartment with half a dozen immigrants in Flatbush and sewed gowns that sold for $\$ 2000$ a piece at a Manhattan boutique.

Bah was 52 and had no criminal record. Yet internal detention documents detailed how he was shackled and pinned to the floor of the detention center's government-staffed medical unit as he moaned and vomited. In a pattern repeated again and again in detention deaths, his symptoms of medical distress - in this case, textbook signs of intracranial bleeding- 
were wrongly labelled a behavior problem. Documents show he was left in a disciplinary cell for more than 13 hours, despite repeated notations that he was unresponsive and foaming at the mouth, despite calls by guards to the medical unit, which dismissed their concerns without checking. And the documents that chronicled all this were labelled "proprietary information-not for distribution" by the Corrections Corporation of America (CCA), the private prison company now called CoreCivic that runs Elizabeth and a dozen other large immigration detention centers for the federal government. The security videotape that captured parts of his ordeal remained hidden for years. Successive ICE investigations, apparently prompted by my renewed inquiries, were narrowly framed to check belatedly for evidence of foul play, not for mistreatment or mistakes; they closed the matter without action. That, too, has been a common pattern.

\title{
THE IMMIGRATION BEAT: BETWEEN PUBLISHING CYCLES, BREAKING STORIES AND ICE
}

At first, I knew none of this. A name alone is not a story. For my editors, the decision to pursue the Bah case was not self-evident, and even at a resource-rich newspaper like the New York Times before the "Great Recession," such reporting had to be squeezed in between other newsroom assignments and the on-going demands of regular immigration coverage. In many ways, immigration is the perfect Metro beat, I had argued in a 2004 memo putting in my bid to cover it.

\begin{abstract}
At its most expansive it demands smart stories that link the local to the global, to national security policy, to constitutional law. At its most intimate, it demands small human tales with the power to surprise or delight our most sophisticated readers. It crosses all the traditional bailiwicks - police, courts, politics, health care, social services, religion, culture, real estate-even fashion. But more than ever these days, it also calls on the investigative skills that can pry information from government agencies and persuade undocumented people to share their secret lives.
\end{abstract}

I had quickly learned, however, that one of the many challenges of covering this somewhat amorphous territory in the post-9/11 era was reconciling the editor's perspective of the beat with the view from the trenches. As Nancy Foner, an anthropologist of immigration, once noted, the memories of the last great wave of immigration are deeply and strongly held. An elaborate mythology has grown around immigration at the turn of the nineteenth century, family lore that celebrates the grit of European 
immigrants who made it in America. That helps explain why editors in New York in the early twenty-first century expected the immigration beat to be a counter-cyclical source of upbeat news stories. When other news is grim-Iraq, terrorism, natural disaster-editors like to be able to serve up features about the heart-warming, the humorous or the off-beat. I worked for a Metro editor who was sure that there were plenty of such stories among three million immigrants living in New York. "Mix it up!" he kept urging me.

The problem was that the stories I found most urgent and compelling tended to be about detention, deportation, the growing power of immigration law as a weapon in the "war on terror," and the growing disconnect between political rhetoric that celebrated immigrant opportunity in America and a darkening reality for many immigrants. Despite public enthusiasm for the speeches of Barack Obama and Arnold Schwarzenegger at the 2004 political conventions, I could see that we were living in a climate of growing hostility to immigration. Economic insecurity had converged with national security concerns - and a new influx of immigrantsto revive the immigration backlash of the early 1990s. Nevertheless, immigration advocacy groups were still lobbying for expansive legislative goals, pushing their own news-they-could-use feature stories on reporters, focusing on subjects like the top student who has lived in this country since childhood but can't go to college unless Congress passes the Dream Act, not to mention a seemingly endless stream of reports, rallies and protestsall distractions from the hard digging and uncertain results of another deep dive into death in detention.

It was the list of names, and the commitment of Margot Williams, an indomitable database researcher, that kept pulling me back into the investigation. The list, though often cryptic and incomplete, turned out to be a crucial road map to the dark places of the detention system as we struggled to locate relatives of other dead detainees. Whenever we did find families, their accounts posed disturbing questions.

In Sacramento, for example, the four sons of Maya Nand were still haunted by the last collect call he had made to them from the CCA detention center in Eloy, Arizona. "This was the first time we ever heard our dad cry," one told me. "He said, 'Son, if you don't get me out of here today, I'm going to die."”

Mr Nand, 56, a legal immigrant from Fiji who was diabetic, had been calling his family collect with mounting desperation over a 10-day period, according to the sons, all US citizens. Doctors didn't take his chest pain and breathing problems seriously, he told them. The family's frantic calls to try to get him care had only reached an answering machine. A lawyer they hired reached the warden, to no avail. That he had been detained at all was 
hard for them to understand. Mr Nand had waited 10 years so he could move the family legally to the United States, in 1998. It was the rejection of his application for US citizenship - because of a 2002 misdemeanor conviction for domestic violence - that apparently prompted his arrest. The misdemeanor had been resolved to the court's satisfaction with a year of anger management classes, but immigration authorities considered it grounds for deportation. And instead of summoning him by letter to immigration court, where he could have fought to stay in the United States, immigration agents had arrested him without warning at his home and shipped him to detention in another state as a "criminal alien," without access to a lawyer.

Mr Nand's 2005 case is highly relevant today because he fits the profile of the "criminal aliens" automatically funnelled into detention under programs that the Obama administration embraced and accelerated. It also illustrates how intertwined the issues of detention health care and due process have become, and why many advocates contend that the most cost-effective and feasible path to better care and better representation for detainees like Mr Nand is not to detain them in the first place.

Asked about Mr Nand's treatment, CCA officials said he had been medically screened when he arrived at the Eloy facility, seen and treated "multiple times" by its medical staff, and taken to a local hospital. Doctors there diagnosed congestive heart failure and later a heart attack, according to a letter to the family from an immigration official. He was airlifted to another hospital in Tucson, on life support, and died there shackled to the bed.

The New York Times posted the government's list of detainee deaths online on 5 May 2008, together with my front-page account of the death of Boubacar Bah and others. Four days later, coincidentally, the Washington Post began publishing a four-part series, "Careless Detention." Its investigation had found, as Dana Priest and Amy Goldstein put it, "a hidden world of flawed medical judgments, faulty administrative practices, neglectful guards, ill-trained technicians, sloppy record-keeping, lost medical files and dangerous staff shortages," that was "also a world increasingly run by high-priced private contractors." 4

What was ICE's response to all this? Officials denied wrongdoing or mistakes in any of the deaths, not disclosing the scathing reports their own investigators had written in several cases. ${ }^{5}$ They showcased the millions of dollars spent on detainee medical care, and pointed to new, performance-based standards to be monitored by inspectors employed by private contractors. Above all, ICE officials deployed statistics that appeared to show that mortality rates in detention were declining, and were low compared with death rates in prisons. Experts in detention 
health care like Dr Homer Venters called the comparison misleading and the trend line wrong. It came to light that the agency was discharging some dying detainees, or deporting them. Eventually I began to suspect a more fundamental problem with the statistics: some deaths had simply disappeared.

But there is a rhythm to newspaper exposés. After we published the list and the story of Boubacar Bah in 2008, a lull in articles about death and medical neglect in detention was almost inevitable, broken only by reporting on congressional hearings and bills spurred by the coverage. Sure, we filed a new, broader FOIA request for all the records relating to detention deaths, but we knew there would be a long wait. Other stories summoned me, including coverage of stepped-up immigration raids and the civil rights litigation that resulted. As immigration became a red-hot political issue, the New York Times launched a paper-wide immigration project, shaped by memos from around the newsroom that proposed long narrative features on many facets of the changes wrought and experienced by the influx of immigrants. My part was to examine the nation's new relationship with immigration detention through the microcosm of Central Falls, Rhode Island, a small, poor, largely Latino city of 19000, where a big detention center had promised jobs and money. Its Donald W. Wyatt Detention Center, nationally accredited, clean and modern, seemed like one of the better jails in the system. In this probe, as I spent months traveling back and forth to Central Falls, alone and then with a photographer, I was exploring the political economy of detention in an immigrant town, not medical neglect inside the barbed wire fence.

But one morning in August 2008, a man died in Wyatt's custody, his spine broken and his body riddled with cancer that had gone undiagnosed until days before his death. It was news that demanded to be written immediately, not held back for the larger project, which still had no publication date in sight. (It would not begin running until late April 2009.) More than other cases, this death seemed to hit home with our readers.

Hiu Lui "Jason" $\mathrm{Ng}$ was a Chinese computer engineer with a US citizen wife and children, a home in Queens, a job in the Empire State building, who had been seized when he went to a green card interview with his wife. Based on a visa overstay and a deportation order in absentia years before, he spent a year in detention, shuttled through several jails in New England while his lawyers battled to reopen his case. When he complained of severe pain that did not respond to analgesics, and grew too weak to walk or even stand to call his family from a detention pay phone, officials accused him of faking his condition. They denied him a wheelchair and refused pleas for an independent medical evaluation. In events captured on security cameras, guards dragged him from his bed and mocked him as he screamed 
in pain, carried him in shackles to a van, and drove him two hours to a federal lockup in Hartford, where an immigration officer pressured him to withdraw all pending appeals of his case and accept deportation. It's worth noting that while these events were unfolding, monitors from the private contractor Nakamoto Group were a constant presence at Wyatt, supposedly making sure that it met ICE performance standards.

Now ICE began its own investigation into Ng's treatment at Wyatt, but unlike so many ICE investigations into detention deaths, this one took place in the spotlight of media attention and legal action. In a highly unusual move, in early December 2008, four months after Ng's death and my frontpage story about it, the government removed all immigration detainees from Wyatt, along with the $\$ 101.76$ a day it had paid the jail for each one. ${ }^{6}$

Where did the detainees go? To other jails in New England, to Louisiana and to Texas. In a sinking economy, immigration detention was a growth industry. As federal spending on detention and removal operations rose, towns from New England to New Mexico had been trying to make the crackdown pay off in deals with detention developers and for-profit prison care providers. As I followed the money, I realized this was a small part of an even larger pattern. The ballooning of detention run for profit, with little oversight, transparency or legal protection for detainees, was unfolding on three continents, along with a history of scandal-riots, escapes, fires, abuse, deaths. ${ }^{7}$

Perhaps the most controversial practice was the detention of children with their parents. In the United States, the T. Don Hutto Family Detention Center, a former state prison near Austin, Texas, had opened in 2006 with 512 beds, drawing an American Civil Liberties Union (ACLU) lawsuit and scathing news coverage for putting young children behind razor wire; it was operated by the CCA under a \$2.8-million-a-month county contract. In Britain, where 7 of 11 detention centers and most short-term holding places for immigrants were run by for-profit contractors by 2010 , some 2000 kids a year were being detained. In one haunting 2005 British case that caught my eye, an Angolan and his 13-year-old son, picked up in a dawn raid at their home in Leeds, had been confined in a private detention center and denied asylum. The father had hanged himself so his son would be released and allowed to finish school in Britain.

"The growth of the detention regime is not based solely on ever-restrictive asylum laws and policies," a 2005 study by the Oxford University Refugee Studies Centre concluded. "Its growth can also be attributed to the involvement of private contractors, whose logic of response to asylum seekers has very little to do with the logic of the government's response, concerned as they are with winning and maintaining contracts and keeping their facilities full." 
Officials justified the expansion of detention as an effort to rein in hostility toward foreigners that had been mounting from Australia and the United States to Norway and France, long before ISIS (Islamic State of Iraq and Syria) heightened public fears. "It is ever more important that proper immigration controls are not only in place but are seen to be in place," Damian Green, Britain's immigration minister, said in the fall of 2009 after opening two new wings of another privately run detention center near Heathrow Airport. "If we do not create public confidence in our immigration system, we will remain vulnerable to those who want to find scapegoats for social problems."

But on the contrary, some analysts contended, the detention and deportation boom legitimized treating foreigners as scapegoats, ratcheting up public anxieties and broader demands for restriction - and deepening the alienation of young people in immigrant communities. "There is this very public display and investment in making these places of confinement look like they're holding dangerous people," said Mary Bosworth, a criminologist at the University of Oxford who tracked the expansion of immigration jails like Yarl's Wood, where the Angolan boy and his father were detained. "It locks the government into the position where it can only get tougher." 10

\section{THE OBAMA ADMINISTRATION AND DETENTION "REFORM"}

In the United States, it was hard to imagine a better window of opportunity for changing this dynamic than the election of Barack Obama, who had campaigned on promises of overhauling immigration policies. Soon after his inauguration in January 2009, his Secretary of Homeland Security, Janet Napolitano, ordered a top to bottom review of the detention system by a special advisor, Dora Schriro. Detention exposés kept coming that spring, in print and on television, including my New York Times investigation of a four-year-old detention death that had virtually vanished from the public record. The difficulty of confirming the very existence of that man, Tanveer Ahmad, a long-time New York City cab driver, showed how little had changed. Even when I was equipped with confirmation, and again requested documents about the man's death from ICE, a Freedom of Information officer had said she was stymied: immigration recordkeepers told her no documents could be located without the dead man's date of birth or eight-digit alien registration number - the same stonewalling response that had all but erased the death of Boubacar Bah during the Bush administration. 
Then in August 2009, two months before the Schriro report was released, the administration handed the New York Times an exclusive advance on the announcement of an ambitious detention overhaul. The offer of an "exclusive" is a classic move designed to win bigger, more prominent news coverage. It is particularly effective when the chosen news outlet has been running critical, investigative coverage of the very problems the announced overhaul is supposed to fix. An inevitable symbiosis is at work. Unless a new administration can quickly show that it is tackling the recently highlighted problems, it will be held responsible for them. A headline announcing reform can win instant credit and breathing room before any reform has been accomplished. For the newspaper, showcasing the administrative response to its own investigative project confirms the importance of its reporting; such follow-up articles are often a factor in the journalistic prizes that help generate support for doing time-consuming investigations in the first place.

In this case, the vehicle for the exclusive was an interview given to me by John Morton, who headed ICE as assistant secretary of Homeland Security. He memorably declared the administration's intention to run "a truly civil detention system." I1 I tried to sound a note of caution or skepticism in my article, pointing out that the Obama administration by then had already adopted many problematic Bush administration policies, bolstering partnerships between federal immigration agents and local police departments, and rejecting a petition for legally binding rules on conditions in immigration detention. Secretary Napolitano had asserted that the number of detainees likely would stay the same or even grow slightly.

As for the proposed overhaul, I wrote,

Details are sketchy, and even the first steps will take months or years to complete. They include reviewing the federal government's contracts with more than 350 local jails and private prisons, with an eye toward consolidating many detainees in places more suitable for non-criminals facing deportation ... The plan aims to establish more centralized authority over the system, which holds about 400000 immigration detainees over the course of a year, and more direct oversight of detention centers that have come under fire for mistreatment of detainees and substandard-sometimes fatal-medical care.

But caveats paled in comparison to the front-page headline- "US to Reform Detention Policy for Immigrants"-and the one immediate and concrete change that Morton announced: the government would stop sending families with children to the hated Hutto detention center. Vanita Gupta, the lead lawyer in the ACLU lawsuit against Hutto, was jubilant, though he noted, "It shouldn't have taken the A.C.L.U. to make 
the government realize that holding innocent children in a converted medium-security adult prison is a bad idea."

Schriro was put in charge of the reform effort, and resigned a month later, just weeks before the release of her eagerly awaited report, finally made public on 6 October 2009.12 The report used dry, understated language, but it was devastatingly critical. The most comprehensive analysis of immigration detention to date, Schriro's report revealed a system that had grown willy-nilly, without even basic tools for measuring performance, or figuring out who was dangerous or a flight risk, let alone who was sick. Outsourced on the fly, some of its contracts paid for jail slots even when they were empty, others got a discount when they were kept full, and the contracting was delegated to field offices plagued with high turnover and lacking expertise. Even the monitoring had been outsourced, to private companies (like Nakamoto) that advocates complained were a revolving door for former private prison wardens and ICE agents who didn't want to offend ICE or the big prison companies.

Schriro underscored that by law the authority of ICE to hold people is purely administrative, not criminal, and not punitive. Yet the system itself was (and remains) almost entirely penal. The population it locks up is overwhelmingly non-violent, including women and children, asylum seekers and long-time legal residents. Detainees can be shackled and shipped anywhere in the country, and while a quarter are in and out of detention in a couple of days, many stay months while the government tries to deport them, and some, including asylum seekers, stay in custody for years. Yet virtually none of the normal due process protections apply, since this kind of detention is not considered to be a loss of liberty, just an administrative measure to return foreigners to the country where they belong.

In political terms, however, the administration had already "gotten ahead" of this report before it was released by announcing the overhaul in advance. Now the focus of news coverage was not on Schriro's findings, but on steps taken since the August announcement. The reform effort included advisory groups soliciting the advice of activists and detainee advocates - in effect, quieting them, if not co-opting them, for many months to come, despite entrenched opposition to change inside the detention infrastructure, where the union of ICE employees and the system's powerful private contractors were allied with politicians and the portion of the public opposed to any leniency on immigration. From the newsroom's perspective, detention issues had been defused. There is little media interest in incremental stories pointing out that a thoroughly criticized system is not fixed yet. Indeed, when thousands of pages of official documents on detention deaths began reaching the New York 
Times and the ACLU through old FOIA requests, including a trail of BlackBerry messages and talking points by managers who had worked to keep the silence, I found myself uncertain how to package them into a fresh and meaningful article.

Once again, Boubacar Bah's case showed the way. The mass of material provided under FOIA included a surveillance videotape of Bah being shackled in the infirmary, and in solitary confinement as he slipped into his fatal coma. A nascent emphasis on video documentaries at the New York Times, and the interest of Rob Harris, a crack videographer then on staff, opened the possibility that this footage could be the lynchpin of a new piece. My own sense of outrage was piqued when my new inquiries about the case at ICE were referred to Michael Gilhooly, the very same spokesman who had lied to me about the Bah case in 2007, under the Bush administration. We also caught up with the career of Nina Dozoretz, one of the officials on a conference call strategizing about how to minimize public fallout from Bah's case. A long-time manager in the Division of Immigrant Health Services who had won an award for cutting detainee health care costs in the Bush administration, she had since become a vice president at Nakamoto, the private contractor that was monitoring the Wyatt detention center when $\mathrm{Ng}$ was dying there. The number of such deaths was now officially at 107. And Ms Dozoretz, I discovered, had just been rehired by the Obama administration to direct the overhaul of detainee health care.

Reader outrage ran high in comments on the front-page article that resulted on 9 January 2010. The piece seemed to unite pro- and antiimmigrant readers in a common anger at government. The biggest surprise: many readers seemed to be hearing about deaths in immigration detention for the first time.

\section{CONCLUSION: WHAT HAS CHANGED?}

Looking back, as I write this chapter in 2016, it is difficult to see what systemic, lasting change these and other investigative articles helped achieve. The Obama administration reopened and expanded family detention, and the United States is now holding more women and children than ever. A small reduction in the total number of immigrants detained, which peaked in 2012, must be weighed against an increase in the criminalization of immigration-related offenses like re-entry after deportation. To the extent that the Obama administration somewhat reduced the number of immigration detention beds in county prisons, it increased those in large for-profit detention centers: private corporations 
now operate 62 percent of all ICE immigration detention beds, up from 49 percent in 2009.13

The traditional news media is in crisis, scrambling to replace imploded business models amid the chaotic and unpredictable rise of social media. Certainly there are some promising aspects to the digital adaptations, including a counter-intuitive appetite for long-form investigative work. But the possibilities of successfully challenging immigration detention through investigative journalism seem slim at the moment. From right and left, the anger at government that I noticed in reader comments fuelled a presidential campaign like no other. Most ominously, it was marked by an explosion of "fake news" on Facebook and Twitter, including virus-like forms of disinformation or propaganda that seemed, with the election of Donald Trump as US president, to herald a new post-factual media era. ${ }^{14}$

During his campaign, Trump promised to deport 11 million unauthorized immigrants and to bar Muslims from entering the country; he called Mexicans rapists and reporters scum. As global refugee challenges escalate and authoritarian, xenophobic movements swell, journalism often seems ill-equipped to defend itself, let alone to be an agent of change. ${ }^{15}$

In a 2010 memo to then-managing editor Jill Abramson, I wrote:

I find it fascinating that at a time of nationalist backlash against global migration, immigration enforcement is increasingly being outsourced to multinationals. I see a rich and important vein of reporting, the possibility of an investigative project that only the Times could tackle ... The global spread of private immigration jails and "immigrant removal centers" has been in many ways an American export. Starting in the Reagan-Thatcher era, English and Danish security firms and a French catering company won the first such contracts in Britain and Australia by partnering with American private prison pioneers, Wackenhut and Corrections Corporation of America. In a kind of blow-back, some of the same overseas companies, after multiple mergers, de-mergers and re-branding, are now major US government contractors of security-related services, including immigration detention and electronic monitoring. Call it the migration-industrial complex.

In the summer of 2011, the New York Times published two articles I had largely researched while on a nine-month leave of absence in Europe, probing this international business of immigration detention and deportation. But that fall the Metro desk assigned me to join the paper's expanding coverage of health care and health care financing, as the battle over the Affordable Care Act heated up. By then, the country's political center of gravity had shifted as Republicans won control of Congress.

It is easy to see in retrospect that larger political currents and the impact of the "Great Recession" sharply limited the clout of any investigative articles relating to immigration during the Obama administration. Despite 
a campaign promise that he would introduce comprehensive immigration reform legislation in his first year of office, in fact immigration ranked lower on Obama's list of domestic priorities than health care. ${ }^{16}$ The same political priorities inevitably affected the New York Times, and coincidentally, perhaps, my own assignments. That said, such investigative journalism becomes part of the larger discourse, cited in law journal articles, editorials and new critical reports by advocacy groups. It no doubt informed an effort by the American Friends Service Committee to press every 2016 presidential candidate about the issue of privatized immigration detention - an effort that prompted Hillary Clinton to say at a debate in Milwaukee: "I've also called for the end of family detention, for the end of privately-run detention centers, along with private prisons, which I think are really against the common good and the rule of law."

Yes, Clinton lost, albeit winning some three million more votes than her opponent. In the strange dialectics of immigration politics, however, Trump's victory may galvanize opposition to detention and deportation among many Americans who were oblivious to the issue when Obama was deporter-in-chief. It may spur new forms of investigative journalism to counter the plague of fake news.

On the other hand, it must be pointed out that the day after Trump's election, private prison stock soared. ${ }^{17}$

\section{NOTES}

1. Hunter et al. (2011), p. 8 .

2. More detailed accounts of these cases and the others cited in this chapter can be found under the byline of the author in the New York Times online archive at https://www. nytimes.com/by/nina-bernstein.

3. Schudson (2015).

4. Priest and Goldstein (2008).

5. Those reports came to my attention much later, in documents obtained through another FOIA request.

6. This official response threatened the newspaper's larger project: how would we be able to use Wyatt, emptied of its immigration detainees in 2008, to illustrate the role of detention in 2009? With difficulty, we broke my article out of the series and into solo publication on 26 December 2008. See Bernstein (2008c).

7. The Global Detention Project (www.globaldetentionproject.org) was an invaluable resource for this international research.

8. Bacon (2005), p. 2.

9. Speech given by Home Office Immigration Minister, Damian Green, at the Royal Commonwealth Society, 6 September 2010. https://www.gov.uk/government/speeches/ immigration-damian-greens-speech-to-the-royal-commonwealth-society (accessed 10 April 2017).

10. Bernstein (2011b).

11. See Bernstein (2009c).

12. Schriro took a job as director of New York City's scandal-plagued Department of 
Correction where she faced similar hardline opposition to a reform agenda. Abuse by Rikers' guards increased during her five-year tenure, and a New York Times investigation found that perpetrators were sometimes protected. See Schwirtz and Winerip (2014) and Schwirtz et al. (2014).

13. See Global Detention Project (2016).

14. See Benton (2016).

15. See Simon (2016).

16. For a discussion of Obama's failed promise of a first-year immigration overhaul, see Hicks (2012).

17. See Stroud (2016).

\section{REFERENCES}

Bacon, Christine (2005), "The Evolution of Immigration Detention in the UK: The Involvement of Private Prison Companies," University of Oxford Working Paper Series, Refugee Studies Centre, Working Paper No. 27, September, p. 2, http://docplayer.net/27654940-University-of-oxford-working-paper-series-rscworking-paper-no-27.html (accessed 10 April 2017).

Benton, Joshua (2016), "The Forces that Drove this Election's Media Failure are Likely to Get Worse," NiemanLab, 9 November, http://www.niemanlab. org/2016/11/the-forces-that-drove-this-elections-media-failure-are-likely-to-getworse/ (accessed 10 April 2017).

Bernstein, Nina (2007a), "New Scrutiny as Immigrants Die in Custody," New York Times, 26 June, http://www.nytimes.com/2007/06/26/us/26detain.html (accessed 10 April 2017).

Bernstein, Nina (2007b), "One Immigrant Family's Hopes Lead to a Jail Cell Suicide," New York Times, 23 February, http://www.nytimes.com/2007/02/23/ nyregion/23suicide.html (accessed 10 April 2017).

Bernstein, Nina (2008a), "Few Details on Immigrants Who Died in Custody," New York Times, 5 May, http://www.nytimes.com/2008/05/05/nyregion/05detain.html (accessed 10 April 2017).

Bernstein, Nina (2008b), "Ill and in Pain, Detainee Dies in U.S. Hands," New York Times, 12 August, http://www.nytimes.com/2008/08/13/nyregion/13detain.html (accessed 10 April 2017).

Bernstein, Nina (2008c), "City of Migrants Fills Jail Cells with its Own," New York Times, 26 December, http://www.nytimes.com/2008/12/27/us/27detain.html (accessed 10 April 2017).

Bernstein, Nina (2009a), "U.S. Issues Scathing Report on Immigrant Who Died in Detention," New York Times, 15 January, http://www.nytimes.com/2009/01/16/ us/16detain.html (accessed 10 April 2017).

Bernstein, Nina (2009b), "Immigrant Detainee Dies, and a Life is Buried, Too," New York Times, 2 April, http://www.nytimes.com/2009/04/03/nyregion/03detain. html (accessed 10 April 2017).

Bernstein, Nina (2009c), "U.S. to Reform Policy on Detention for Immigrants," New York Times, 5 August, http://www.nytimes.com/2009/08/06/us/politics/06detain. html (accessed 10 April 2017).

Bernstein, Nina (2010), "Officials Hid Truth of Immigrant Deaths in Jail," New York Times, 9 January, http://www.nytimes.com/2010/01/10/us/10detain.html (accessed 10 April 2017). 
Bernstein, Nina (2011a), "Companies Use Immigration Crackdown to Turn a Profit," New York Times, 28 September, http://www.nytimes.com/2011/09/29/world/asia/ getting-tough-on-immigrants-to-turn-a-profit.html (accessed 10 April 2017).

Bernstein, Nina (2011b), "In Father's Memory, Fighting to Stay in Britain," New York Times, 20 August, http://www.nytimes.com/2011/08/21/world/europe/21antonio. html (accessed 10 April 2017).

Global Detention Project (2016), "Immigration Detention in the United States," May, https://www.globaldetentionproject.org/countries/americas/united-states (accessed 10 April 2017).

Harris, Rob and Nina Bernstein (2010), "What Really Happened to Boubacar Bah?," New York Times, 10 January, Video, https://www.nytimes.com/video/nyregion/1247466467222/what-really-happened-to-boubacar-bah.html (accessed 10 April 2017).

Hicks, Josh (2012), “Obama's Failed Promise of a First-year Immigration Overhaul," Washington Post, 25 September, https://www.washingtonpost.com/ blogs/fact-checker/post/obamas-failed-promise-of-a-first-year-immigration-ove rhaul/2012/09/25/06997958-0721-11e2-a10c-fa5a255a9258_blog.html (accessed 10 April 2017).

Hunter, Mark Lee (2011), "Story-Based Inquiry: A Manual for Investigative Journalists," UNESCO,p. 8, http://unesdoc.unesco.org/images/0019/001930/193078 e.pdf (accessed 10 April 2017).

Priest, Dana and Amy Goldstein (2008), "Careless Detention: A System of Neglect," Washington Post, 11 May, http://www.washingtonpost.com/wp-srv/ nation/specials/immigration/cwc_d1p1.html (accessed 10 April 2017).

Schudson, Michael (2015), "Where the Right to Know Comes From," The Columbia Journalism Review, Wikimedia Commons, 14 October, http://www.cjr. org/b-roll/where_the_right_to_know_comes_from.php (accessed 10 April 2017).

Schwirtz, Michael and Michael Winerip (2014), "Violence by Rikers Guards Grew Under Bloomberg," New York Times, 13 August.

Schwirtz, Michael, Michael Winerip and Benjamin Weiser (2014), "Report Found Distorted Data on Jail Fights at Rikers Island," New York Times, 21 September.

Simon, Joel (2016), "Why Journalists Should be Afraid of Trump's Media Strategy," Columbia Journalism Review, 14 March, http://www.cjr.org/first_person/why_ journalists_should_be_afraid_of_trumps_media_strategy.php (accessed 10 April 2017).

Stroud, Matt (2016), "Private Prisons Get a Boost from Trump," Bloomberg, 18 November, http://www.bloomberg.com/news/articles/2016-11-18/private-prisonsget-a-boost-from-trump (accessed 10 April 2017). 